\title{
18. PLIOCENE-PLEISTOCENE RADIOLARIAN BIOSTRATIGRAPHY AND PALEOCLIMATOLOGY AT DSDP SITE 278 ON THE ANTARCTIC CONVERGENCE
}

\author{
John Keany and James P. Kennett, Graduate School of Oceanography, \\ University of Rhode Island, Kingston, Rhode Island
}

\begin{abstract}
Siliceous-rich sediments of late Pliocene to early Pleistocene age at DSDP Site 278, located on the Antarctic Convergence, contain an excellent radiolarian biostratigraphic and paleoclimatic record. The radiolarian zonation indicates that the middle Pliocene is missing in a disconformity. Three radiolarian zones are recognized above the disconformity, and from comparison with previous piston core studies, indicate a continuous biostratigraphic sequence from the early part of the Brunhes Normal paleomagnetic epoch $(0.69$ m.y.B.P.) to the earliest part of the Matuyama Reversed Epoch (2.40 m.y.B.P.). Oscillations in the frequency of the cool-water radiolarian Antarctissa strelkovi indicate 9 or 10 warm-water episodes during that part of the Matuyama Reversed Epoch represented, with one warm-water episode inferred to be missing in the disconformity. The most important radiolarian species are illustrated by SEM and LM photographs.
\end{abstract}

\section{INTRODUCTION}

DSDP Site 278 is located on the Antarctic Convergence in the southern Emerald Basin (lat $56^{\circ} 33.42^{\prime} \mathrm{S}$, long $160^{\circ} 04.29^{\prime} \mathrm{E}$; water depth: $3669 \mathrm{~m}$ ) (Figure 1). The upper 170 meters is comprised of siliceous ooze of late Pliocene to Pleistocene age. These overlie early to late Miocene nannofossil or siliceous oozes in turn overlying siliceous nannofossil chalk of middle Oligocene to earliest Miocene age. Latitudinal fluctuations of the Antarctic Convergence during the late Cenozoic appear to have been minimal in the vicinity of Site 278 due to its close proximity to the southern end of the Macquarie Ridge. In the present day, the Antarctic Convergence is diverted to the south by the barrier to circum-polar flow created by the north-south trending Macquarie Ridge (Gordon, 1972). The resulting stable position of the Antarctic Convergence has caused prolonged high sedimentation rates $(>8$ $\mathrm{cm} / 1000 \mathrm{yr}$ ) during the late Cenozoic, resulting from the high biogenic activity associated with the Antarctic Convergence. Site 278 is thus an excellent sequence for late Cenozoic biostratigraphic and paleoclimatic

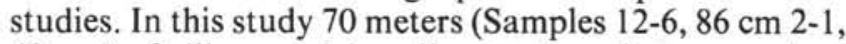
$40 \mathrm{~cm}$ ) of siliceous-rich sediments have been examined to establish a radiolarian zonation for the sediments of late Pliocene-early Pleistocene age, to infer paleomagnetic ages, and to establish a paleotemperature curve. ${ }^{\top}$

'Fluctuations in ice-rafted debris in Site 278 are described by Margolis (Chapter 30; this volume).
Micropaleontological investigations on Southern Ocean sediments of late Pliocene-early Pleistocene age (Matuyama Reversed Epoch, 2.43 m.y.B.P.-0.69 m.y.B.P.) have previously been restricted to short piston cores where continuous Matuyama sequences were

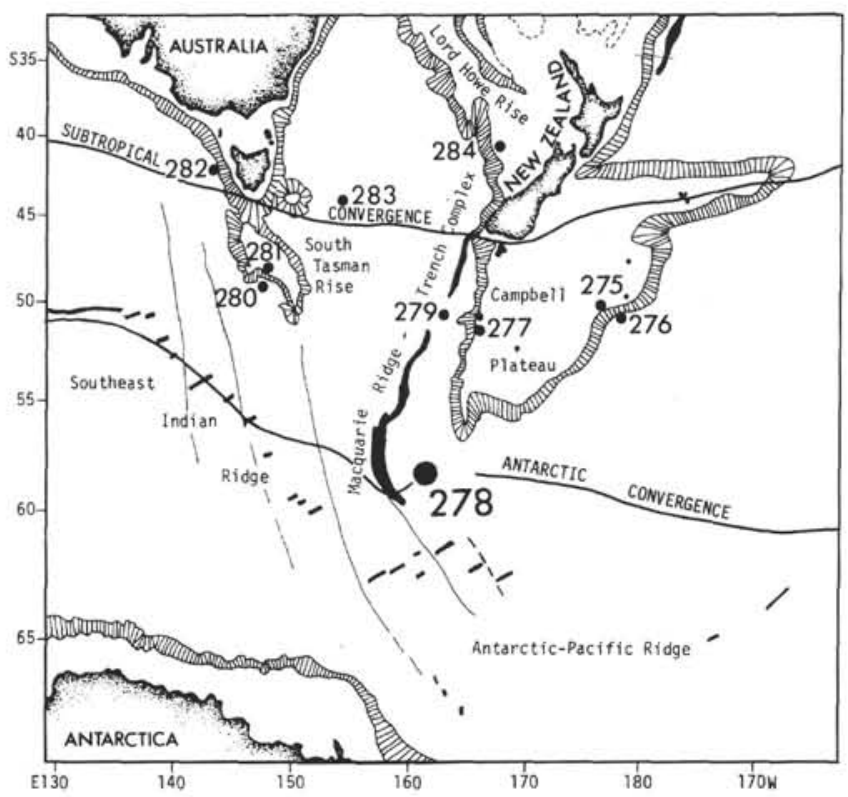

Figure 1. Location of DSDP Site 278, and the positions of the Antarctic and Subtropical convergences (after Macintosh (1946) and Garner (1959). 
generally less than 6 meters thick. These studies have, however, established a radiolarian zonation for Antarctic-Subantarctic deep-sea sediments (Hays, 1965) and correlation of these radiolarian zones with paleomagnetic stratigraphy (Opdyke et al., 1966; Hays and Opdyke, 1967; Bandy et al., 1971; Keany and Kennett, 1972). Correlation of biostratigraphy with paleomagnetic stratigraphy allows accurate dating of cores.

Paleoclimatic investigations on sediments of Matuyama age in the Southern Ocean using foraminifera (Keany and Kennett, 1972) and Radiolaria (Bandy et al., 1971; Keany, 1973) have defined 10 or 11 warm episodes during the Matuyama Reversed Epoch. Detailed investigations of the paleoclimatic history of the Matuyama in the Southern Ocean have been delayed by a lack of long, continuous sections. The Deep Sea Drilling Program is now providing such sections.

\section{Materials and Methods}

Samples taken at intervals of approximately 100-150 $\mathrm{cm}$ were washed through a 63-micron sieve. Slides of representative radiolarian populations were prepared using standard laboratory procedures. The slides were qualitatively examined to determine the radiolarian species present. For sediments of Matuyama age, total slide populations (500-1200 specimens) were counted to determine the percentage of Antarctissa strelkovi in each sample.

\section{RADIOLARIAN BIOSTRATIGRAPHY}

Ranges of radiolaria and radiolarian zones are shown in Figure 2 for the interval from 101 to 206 meters (Samples 12, CC to 2-1, $40 \mathrm{~cm}$ ). The fauna of Cores 9-12 are marked by the presence of Triceraspyris sp. (Plate 2, Figures 9, 10) Lychnocanium grande rugosum, Prunopyle titan (Plate 2, Figure 11), Desmospyris spongiosa (Plate 2, Figures 13, 14), Clathrocyclas cf. bicornis (Plate 3, Figure 12) and Dictyophimus sp. (Plate 2, Figure 12; Plate 3, Figures 10,11). The fauna is early Pliocene in age because of the abundance of Dictyophimus sp., and because $C$. cf. bicornis has a spongy structure which is quite distinct from the tests of $C$. bicornis in the late Pliocene.

A sharp change in the fauna occurs at 167.5 meters (between Samples 9-1, $40 \mathrm{~cm}$ and 8, CC). This level marks the abrupt upper limit of several species including Prunopyle titan and Dictyophimus sp., and the sudden appearance of several species including Antarctissa strelkovi (Plate 1, Figures 13, 14), Antarctissa denticulata (Plate 1, Figures 9, 10), and Spongoplegma antarcticum (Plate 1, Figure 3).

The fauna between 158 and 167.5 meters is typical of the $\Phi$ Zone (Hays and Opdyke, 1967) of late Pliocene age, containing Clathrocyclas bicornis (Plate 2, Figures 2, 3), and Eucyrtidium calvertense (Plate 2, Figure 4). The radiolarian biostratigraphy indicates that a major disconformity occurs at 167.5 meters $(8, C C)$ which has eliminated a large section of the middle Pliocene (including the lowermost Matuyama Reversed, the entire Gauss Normal and the upper part of the Gilbert Reversed).

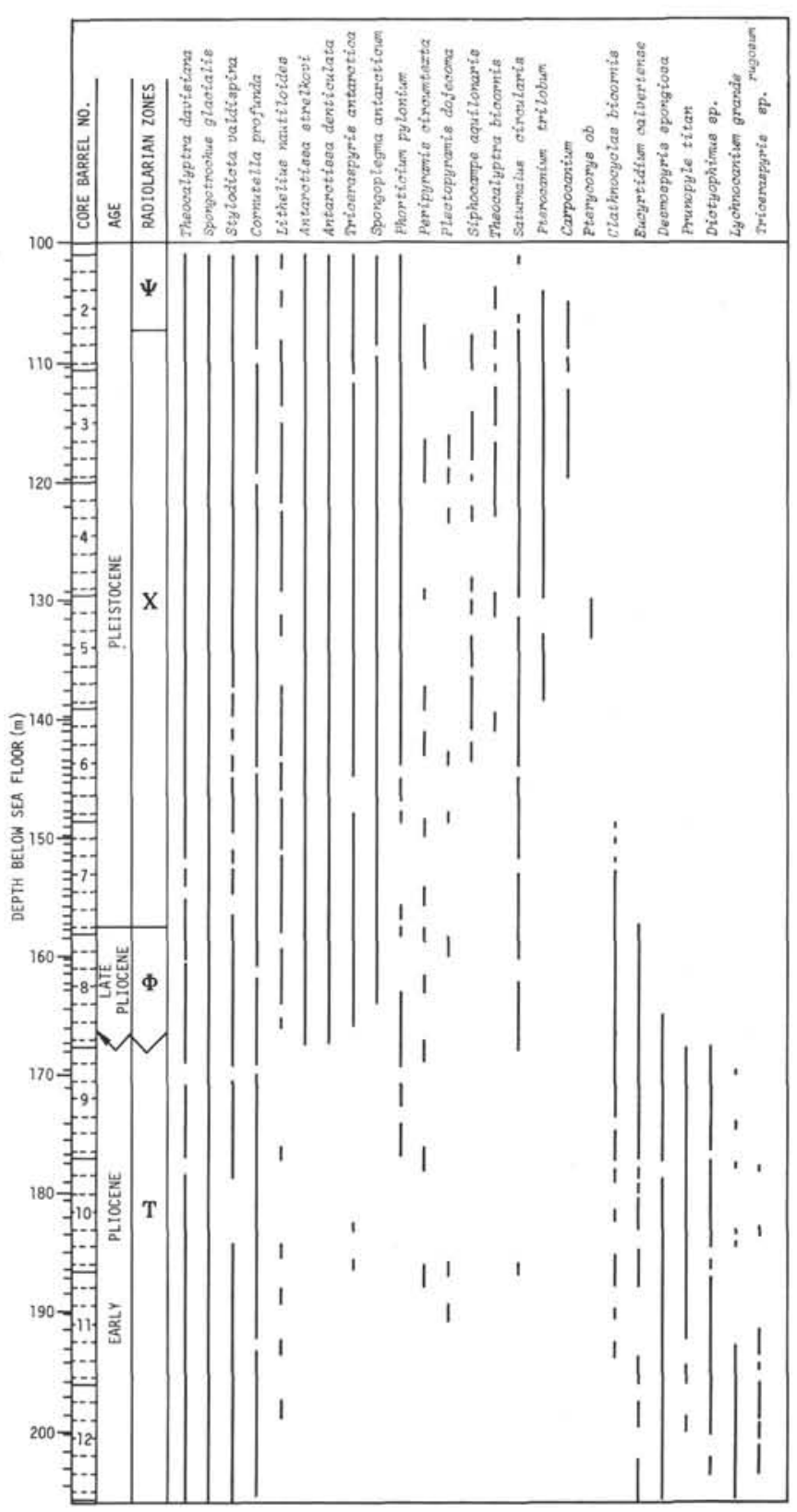

Figure 2. Radiolarian ranges in DSDP Site 278, Cores $2-12$ showing thickness of section in meters, core numbers, radiolarian zones (after Hays, 1965), and age. A substantial disconformity occurs at 167.5 meters.

The uppermost boundary of the $\Phi$ Zone, marked by the disappearance of $E$. calvertense, coincides approximately with the base of the Gilsa Event (1.79 m.y.B.P.); the Pliocene-Pleistocene boundary occurs at 158 meters (between Samples 7-6, $40 \mathrm{~cm}$ and 7, CC).

The upper limit of $C$. bicornis has been shown to coincide approximately with the upper boundary of the Gilsa Event (1.61 m.y.B.P.) (Hays and Opdyke, 1967) 
and so the inferred upper boundary of the Gilsa Event is placed at approximately 150 meters (between Samples 7$1,40 \mathrm{~cm}$ and $7-1,140 \mathrm{~cm}$ ).

The $\Psi-\chi$ boundary, which coincides closely with the Brunhes-Matuyama boundary (Hays and Opdyke, 1967), is marked by the last appearance in AntarcticSubantarctic waters of Saturnalus circularis (Plate 1, Figure 6), Pterocanium trilobum (Plate 1, Figure 5), and Carpocanium sp. (Plate 1, Figure 7; Plate 3, Figure 2). The Brunhes-Matuyama boundary occurs at approximately 107 meters (between Samples $2-4,40 \mathrm{~cm}$, and $205,40 \mathrm{~cm}$ ).

\section{PALEO-OCEANOGRAPHY}

Keany (1973) demonstrated that frequency oscillations of the cold-water radiolarian Antarctissa. strelkovi are closely related to paleoclimatic oscillations based on planktonic foraminifera (Keany and Kennett, 1972). Increased frequencies of $A$. strelkovi consistently correlate with colder intervals.

Oscillations in the frequency of $A$. strelkovi were recorded for the almost continuous sequence of Matuyama age at Site 278. The oscillations define at least 9 or 10 warm intervals for that part of the Matuyama present in the core (Figure 3). A. strelkovi ranges from $13 \%$ to $39 \%$ of the total fauna, with an average of about $20 \%$. This is comparable to fluctuations for Matuyama age sediments in piston cores at similar latitudes (Keany, 1973). For the sections of Core 4 where no samples were available, the paleoclimatic curve has been inferred.

The radiolarian paleoclimatic curve for this site (Figure 4), shows a good correlation with the previously established paleoclimatic curve (Keany and Kennett, 1972). The most rapid paleoclimatic oscillations occur immediately after the Pliocene-Pleistocene boundary, where Peaks 12 and 13 appear to actually consist of several rapid oscillations. Peaks 14 and 15 in the zone are clearly visible, while Peak 16 is missing in the disconformity. The radiolarian curve suggests the presence of a previously unrecorded warm peak between Peaks 9 and 10 , although this possibly results from drilling disturbances in Core 4.

The disconformity located at 167.5 meters suggests strong submarine erosion, at least during the latest Gauss-earliest Matuyama. A cooling in the Southern Ocean and temperate regions beginning in the latest Gauss, and continuing into the Matuyama has been described by Kennett et al. (1971); Keany and Kennett (1972); Kennett and Vella (this volume); and Shackleton and Kennett (this volume). Watkins and Kennett (1971) attribute increased erosion in the Southern Ocean and Tasman Sea to an increase in bottom-water production and velocities occurring in post-Gilbert or post-Gauss time. This, in turn, resulted from increased Antarctic glaciation. Fillon (1972) found a widespread disconformity extending over basins and ridges in the Ross Sea, and suggested that erosion resulted from enhanced bottom-water activity occurring subsequent to the late Gauss. The disconformity is an extensive, widespread feature in the Southern Ocean, and represents a fundamental change that occurred in bottom-water activity in post-Gauss time.

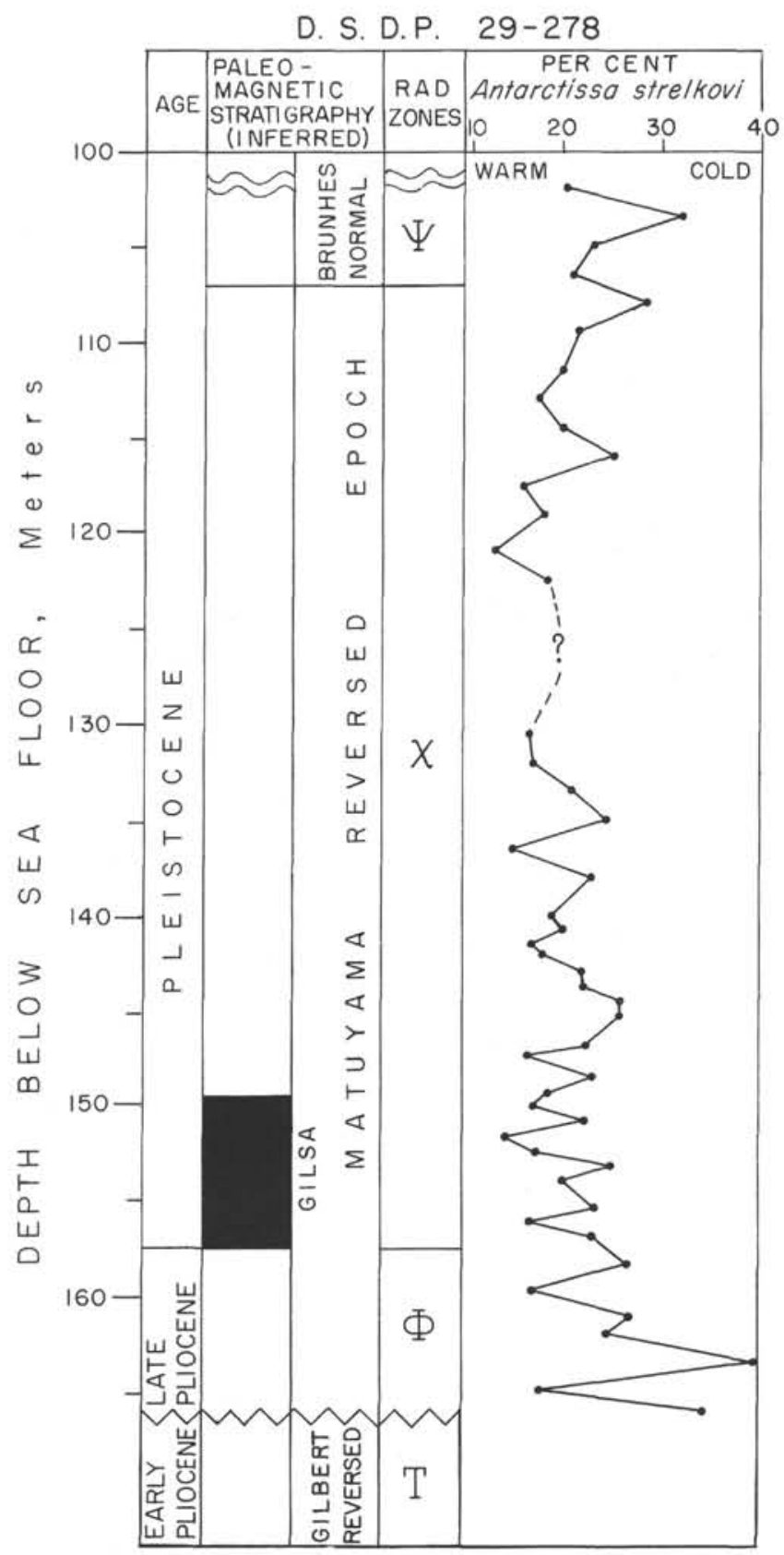

Figure 3. Data for Site 278 showing age, inferred paleomagnetic stratigraphy, radiolarian zones (after Hays, 1965), and percent of Antarctic radiolarian Antarctissa strelkovi.

\section{CONCLUSIONS}

1. Site 278 contains an almost continuous sequence of siliceous-rich sediments of late Pliocene-early Pleistocene age $(101-167.5 \mathrm{~m})$. The radiolarian biostratigraphy indicates an almost complete Matuyama Reversed Epoch, encompassing the $\chi$ radiolarian zone and a portion of the $\Phi$ radiolarian zone.

2. Frequency oscillations of the Antarctic radiolarian Antarctissa strelkovi define 9 or 10 warm episodes in that part of the Matuyama as preserved at Site 278. 


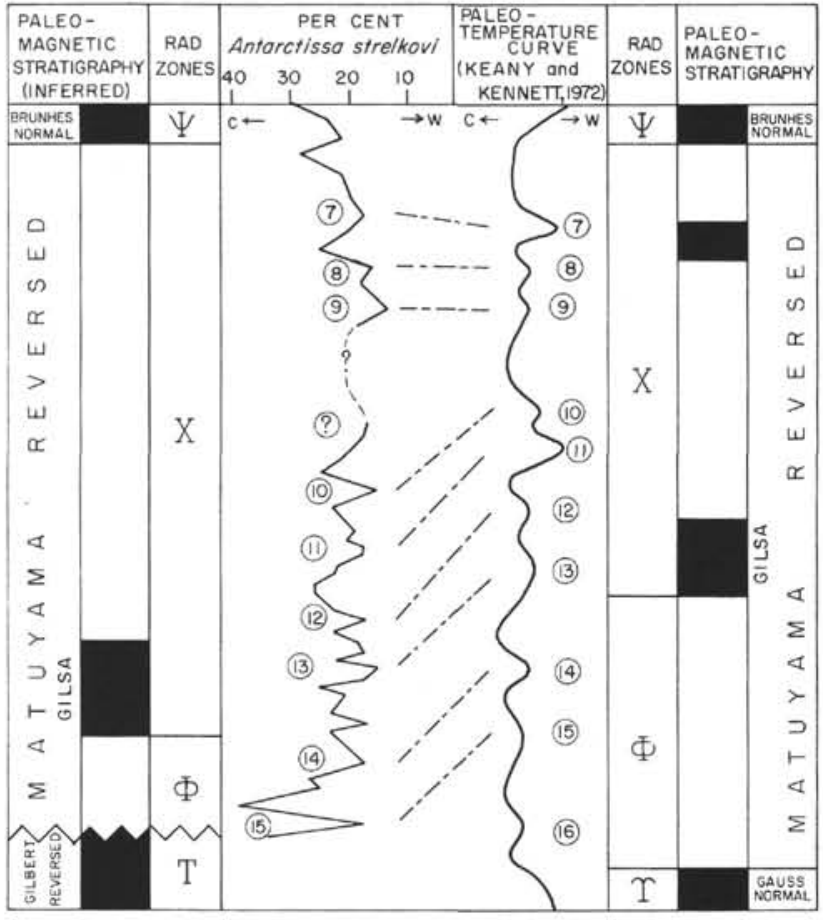

Figure 4. Comparison of frequency curve of Antarctissa strelkovi and numbered warm episodes with generalized foraminiferal paleoclimatic curve and warm episodes recognized by Keany and Kennett (1972). On the left is shown inferred paleomagnetic stratigraphy for the Pliocene and early Pleistocene of Site 278 and radiolarian zones (Hays, 1965). The generalized paleoclimatic curve on right was correlated by Keany and Kennett (1972) with the radiolarian zones of Hays (1965) and paleomagnetic stratigraphy after Cox (1969).

3. A substantial disconformity at 167.5 meters, marked by abrupt changes in the radiolarian biostratigraphy, has eliminated much of the middle Pliocene (including lowermost Matuyama, the entire Gauss, and uppermost Gilbert). The disconformity appears to be related to a major increase in bottomwater activity in the Southern Ocean after the Guass Normal Epoch.

\section{ACKNOWLEDGMENTS}

The SEM photographs were taken at the University of Rhode Island by Donald Scales and Eric Cieplik. This research was partially supported by National Science Foundation grant GV-28305. The SEM facility at the University of Rhode Island was established with the assistance of a grant from the National Science Foundation (Oceanography Division; GA-28905).

\section{REFERENCES}

Bandy, O. L., Casey, R. E., and Wright, R. C., 1971. Late Neogene planktonic zonation, magnetic reversals, and radiometric dates, Antarctic to tropics: Am. Geophys. Union, Antarctic Res. Ser., v. 15, p. 1-26.

Cox, A., 1969. Geomagnetic reversals: Science, v. 163, p. $237-$ 245.

Fillon, R. H., 1972. Evidence from the Ross Sea for widespread submarine erosion: Nature Phys. Sci., v. 238, p. 40-42.

Garner, D. M., 1959. The sub-tropical convergence in New Zealand surface waters: New Zealand J. Geol. Geophys., v. 2, p. 315-337.

Gordon, A. L., 1972. On the interaction of the Antarctic circumpolar current and the Macquarie Ridge: Am. Geophys. Union, Antarctic Res. Ser. v. 19, p. 71-78.

Hays, J. D., 1965. Radiolaria and late Tertiary and Quaternary history of Antarctic seas: Am. Geophys. Union, Antarctic Res. Ser., v. 5, p. 125-184.

Hays, J. D. and Opdyke, N. D., 1967. Antarctic Radiolaria, magnetic reversals, and climatic change: Science, v. 158, p. 1001-1011.

Keany, J., 1973. New radiolarian palaeoclimatic index in the Plio-Pleistocene of the Southern Ocean: Nature v. 246, p. 139-141.

Keany, J. and Kennett, J. P., 1972. Pliocene-early Pleistocene paleoclimatic history recorded in Antarctic-Subantarctic deep-sea cores: Deep-Sea Res., v. 19, p. 529-548.

Kennett, J. P., Watkins, N. D., and Vella, P., 1971. Paleomagnetic chronology of Pliocene-early Pleistocene climates and the Plio-Pleistocene boundary in New Zealand: Science, v. 171 , p. 276-279.

Mackintosh, N. A., 1946. The Antarctic convergence and the distribution of surface temperatures in Antarctic waters: Discovery Rep., v. 23, p. 177-212.

Opdyke, N. D., Glass, B., Hays, J. D., and Foster, J., 1966. Paleomagnetic study of Antarctic deep-sea cores: Science, v. 154 , p. $349-357$.

Watkins, N. D. and Kennett, J. P., 1971. Antarctic bottom water: major changes in velocity during the late Cenozoic between Australia and Antarctica: Science, v. 173, p. 813818 . 



\section{PLATE 1}

Figure 1 Stylotracta universa Hays.

278-2-1, 40-42 cm; $\times 165$.

Figure 2 Theocalyptra davisiana (Ehrenberg).

278-2-4, 90-92 cm; $\times 380$.

Figure 3 Spongoplegma antarcticum Haeckel. 278-3-6, 90-92 cm; $\times 140$.

Figure $4 \quad$ Stylochlamidium $\mathrm{sp}$. 278-5-3, 90-92 cm; $\times 245$.

Figure 5 Pterocanium trilobum Haeckel. 278-5-3, 90-92 cm; $\times 180$.

Figure 6 Saturnalus circularis (Haeckel). 278-5-1, 90-92 cm; $\times 165$.

Figure 7 Carpocanium sp.

278-5-3, 90-92 cm; $\times 530$.

Figure $8 \quad$ Pterycorys ob. Petrushevskaya. 278-5-1, 90-92 cm; $\times 260$.

Figures 9, 10 Antarctissa denticulata Petrushevskaya.

9. 278-5-1, 90-92 cm; $\times 415$.

10. $278-6-3,90-92 \mathrm{~cm} ; \times 380$.

Figure $11 \quad$ Peripyramis circumtexta Haeckel. 278-2-4, 90-92 cm; $\times 245$.

Figure 12 Spongotrochus glacialis Popofsky. 278-12-6, 86-88 cm; $\times 100$.

Figures 13, 14 Antarctissa strelkovi Petrushevskaya. 13. $278-8-2,14-16 \mathrm{~cm} ; \times 440$. 14. $278-3-6,90-92 \mathrm{~cm} ; \times 400$.

Figure 15 Plectopyramis dodecoma Haeckel. 278-2-4, 90-92 cm; $\times 140$.

Figure 16 Phorticium pylonium (Haeckel). 278-5-3, 90-92 cm; $\times 270$. 


\section{PLATE 1}
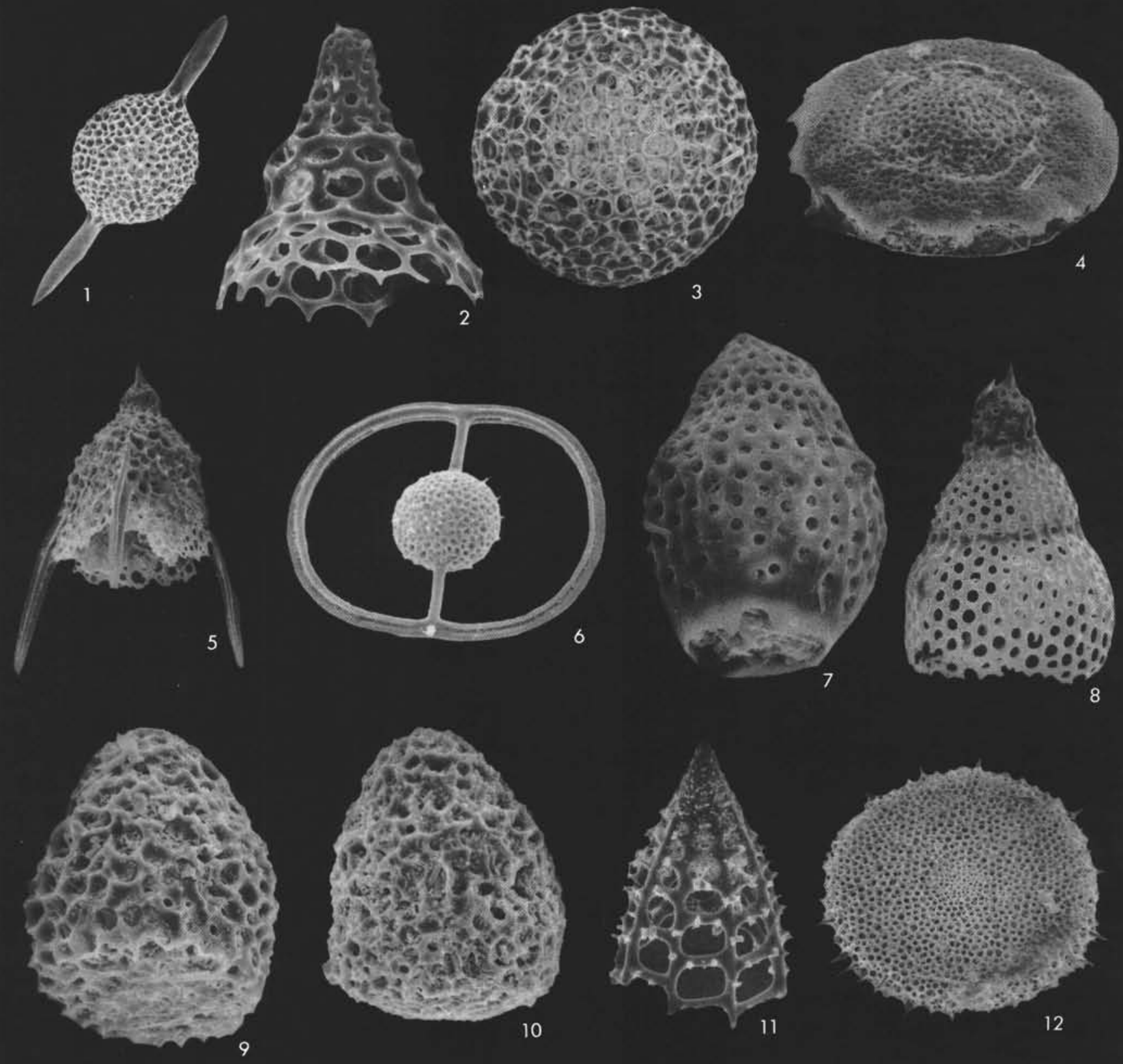

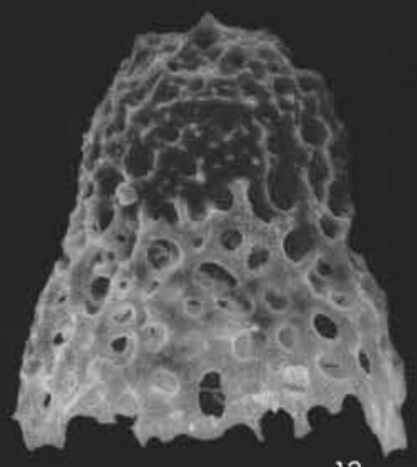

13
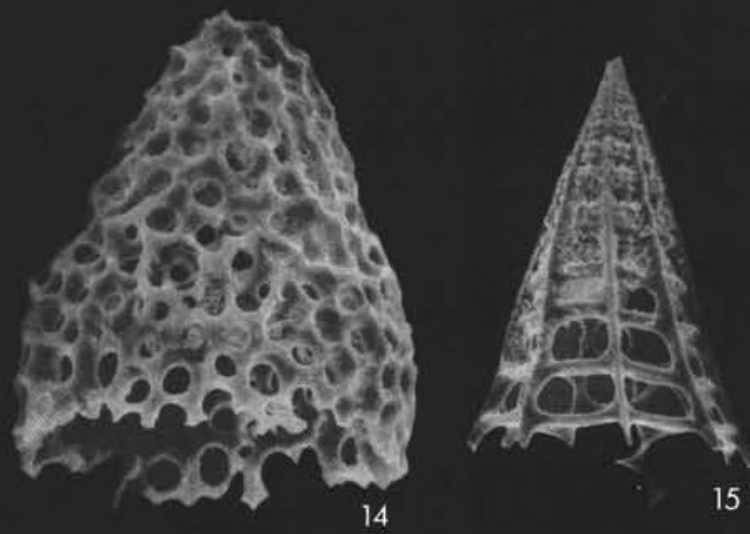

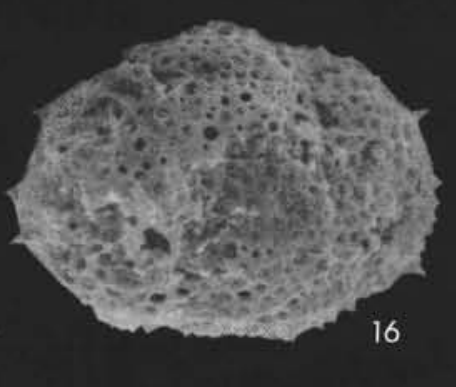




\section{PLATE 2}

Figure 1 Lophophaena sp.

278-2-4, 90-92 cm; $\times 315$.

Figures 2, 3 Clathrocyclas bicornis Hays.

2. $29-278-7-5,40-42 \mathrm{~cm} ; \times 245$.

3. $29-278-7-5,40-42 \mathrm{~cm} ; \times 195$.

Figure 4 Eucyrtidium calvertense Martin. 278-12-6, 86-88 cm; $\times 245$.

Figure 5 Cornutella profunda Ehrenberg. 278-5-3, 90-92 cm; $\times 255$.

Figure $6 \quad$ Euchitonia sp. 278-12-8, 86-88 cm; $\times 155$.

Figures 7, 8 Spongurus pylomaticus Riedel.

7. $278-12-6,86-88 \mathrm{~cm} ; \times 245$.

8. $278-12-6,86-88 \mathrm{~cm} ; \times 185$.

Figures 9, 10 Triceraspyris sp. Hays.

9. 278-10-4, 90-92 cm; $\times 355$.

10. $278-10-4,90-92 \mathrm{~cm} ; \times 365$.

Figure $11 \quad$ Prunopyle titan Campbell and Clark. 278-9-5, 40-42 cm; $\times 260$.

Figure 12 Dictyophimus sp.

278-10-2, 90-92 cm; $\times 335$.

Figures 13, 14 Desmospyris spongiosa Hays.

13. $278-12-6,86-88 \mathrm{~cm} ; \times 400$.

14. $278-10-4,90-92 \mathrm{~cm} ; \times 320$.

Figure $15 \quad$ Collosphaerid sp.

278-12-6, 86-88 cm; $\times 145$.

Figure 16 Theocyrtis redondoensis Campbell and Clark 278-10-2, 90-92 cm; $\times 300$. 


\section{PLATE 2}
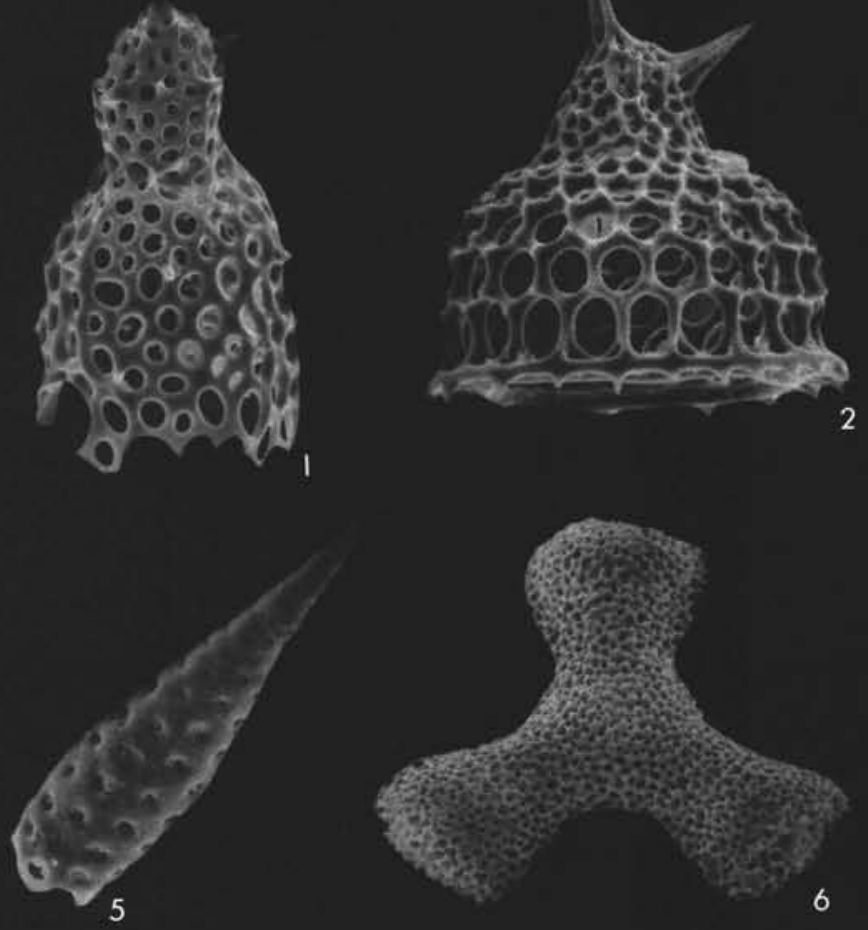

6
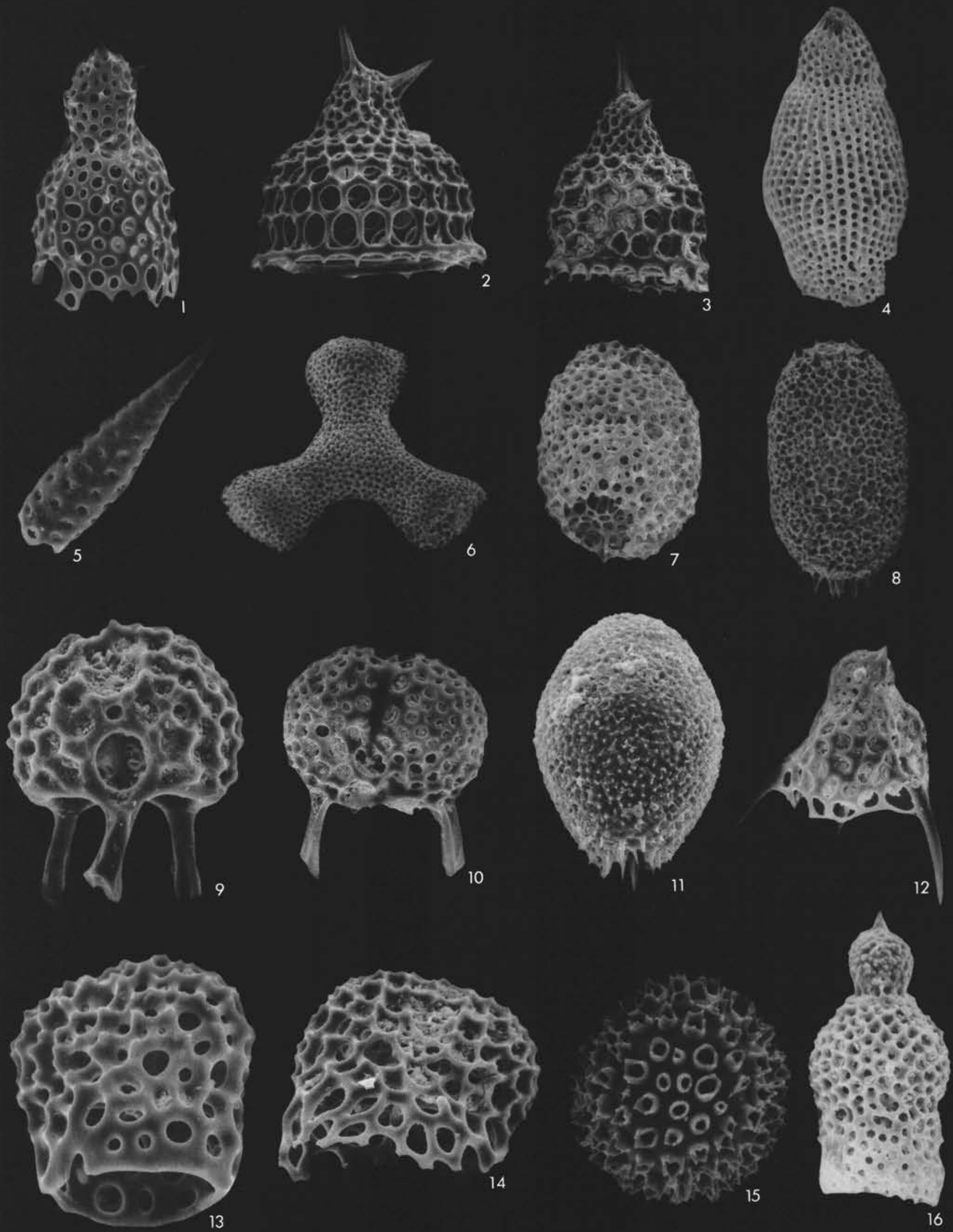


\section{PLATE 3}

Figure 1 Spongopyle osculosa Dreyer. 278-8-2, 140-142 cm; $\times 115$.

Figure 2 Carpocanium sp.

$278-2-5,40-42 \mathrm{~cm} ; \times 165$.

Figure 3 Theoconus zancleus Haeckel. 278-5-1, 40-42 cm; $\times 255$.

Figure $4 \quad$ Prunopyle tetrapila Hays. 278-8-1, 30-32 cm; $\times 145$.

Figure 5 Theocalyptra davisiana (Ehrenberg). 278-8-2, 140-142 cm; $\times 270$.

Figure $6 \quad$ Phorticium clevei (Jorgensen). 278-5-1, 40-42 cm; $\times 140$.

Figure $7 \quad$ Stylodicta valdispina Jorgensen. 278-5-4, 40-42 cm; $\times 205$.

Figure 8 Desmospyris spongiosa Hays. 278-9-6, 40-42 cm; $\times 230$.

Figure 9 Cenosphaera cristata Haeckel. 278-2-2, 40-42 cm; $\times 170$.

Figures 10, 11 Dictyophimus sp.

10. $278-10-3,40-42 \mathrm{~cm} ; \times 445$.

11. $278-10-3,40-42 \mathrm{~cm} ; \times 330$.

Figure $12 \quad$ Clathrocyclas cf. bicornis 278-9-1, 40-42 cm; $\times 205$. 


\section{PLATE 3}
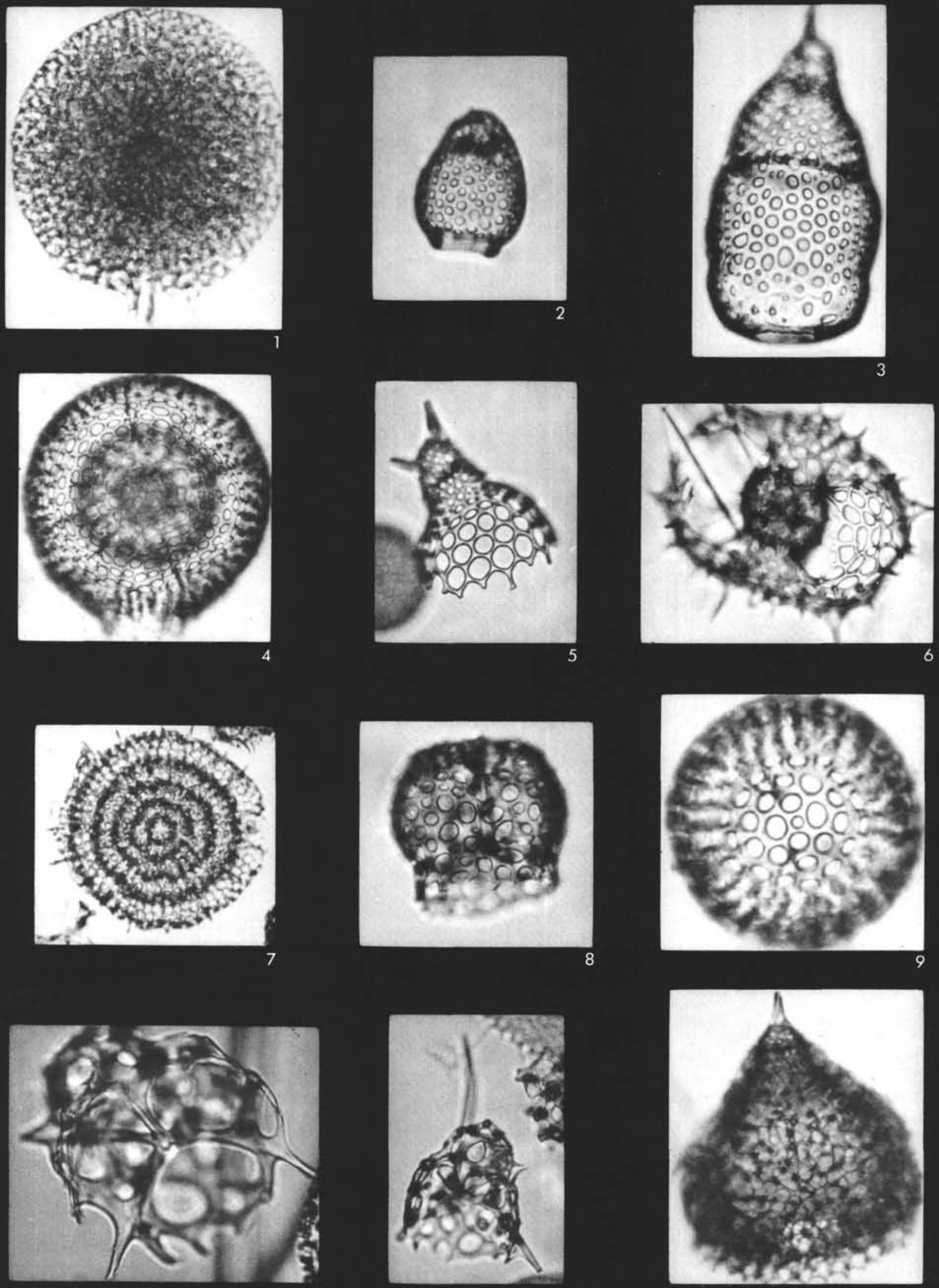